\title{
Men, Suicide, and Covid-19: Critical Masculinity Analyses and Interventions
}

\author{
Anisur Rahman Khan ${ }^{1} \cdot K_{\text {Kopano Ratele }}^{2} \cdot$ Najuwa Arendse $^{2}$ \\ Published online: 25 June 2020 \\ (C) Springer Nature Switzerland AG 2020
}

Keywords Covid-19 $\cdot$ Pandemic $\cdot$ Men $\cdot$ Suicide $\cdot$ Masculinity $\cdot$ Interventions

\section{Men's Susceptibility to Suicide During the Covid-19 Pandemic}

Suicide is a global public health burden, causing around 800,000 deaths annually along with many more attempts (World Health Organization 2019). Since Émile Durkheim's classic study Le Suicide (Durkheim 1951), it has been repeatedly confirmed that suicide rates spike up during and after crises (Chang, Stuckler, Yip, and Gunnell 2013; Iemmi et al. 2016; Gunnell et al. 2020). Recent research reports indicate that various socioeconomic, psychological, and health-related impacts of the Covid19 pandemic may heighten the risk of suicidal behaviors (Reger, Stanley, and Joiner 2020; Gunnell et al. 2020). Uncertainties caused by the Covid-19 pandemic, coupled with global responses such as lockdowns, have heightened depression, anxiety, isolation, loneliness, financial concerns, anger, irritability, relationship conflicts, post-traumatic stress disorder, fears, and increased use of alcohol and tobacco (Tull et al. 2020; Courtet, Olié, Debien, and Vaiva 2020). Factors like these intensify risk from suicidal behaviors in people who are traditionally considered as vulnerable and in people who were not considered at risk prior to the pandemic (Suicide Awareness Voices of Education 2020; Courtet et al. 2020).

Anisur Rahman Khan

arkhan@ewubd.edu

Kopano Ratele

kopano.ratele@mrc.ac.za

Najuwa Arendse

najuwa.arendse@mrc.ac.za

1 Department of Sociology, East West University, Dhaka, Bangladesh

2 Masculinity and Health Research Unit, South African Medical Research Council-University of South Africa/Institute for Social and Health Sciences, University of South Africa, Cape Town, South Africa 
Men demonstrate higher suicide rates than women at all times and across regions and ethnic and socioeconomic groups (Vijayakumar 2015; Naghavi 2019; Cleary 2019), and current sources indicate similar trends during the Covid-19 pandemic (Mooney, Kaplan, and Denis 2020). A recent online international newspaper review attributes 15 suicide cases, 2 suicide attempts, and 1 homicide-suicide to the concomitant impact of Covid-19. All victims except one were men, from all tiers of society (Khan, Arendse, and Ratele 2020). Another international review reports 7 suicide cases associated with the Covid-19 pandemic, 5 of which were men (Thakur and Jain 2020). A country-specific review in Pakistan identifies 12 suicide cases and 4 suicide attempts related to Covid-19; 12 comprised men who suffered serious economic hardships during the pandemic (Mamun and Ullah 2020). Another country-specific review in Bangladesh captures 9 suicide cases associated with Covid-19, 5 of which were men who encountered financial constraints induced by the pandemic (Bhuiyan, Sakib, Pakpour, Griffiths, and Mamun 2020). This preliminary data is still far from complete, and newspaper stories are often ridden with exaggerations and sensationalism. However, positive correlation between longitudinal studies and recent reports indicates that male suicide during the Covid-19 pandemic requires dedicated attention.

\section{Critical Masculinity and Male Suicide}

Critical analyses of masculinity situate higher male vulnerability to suicide in a wide sociocultural context (Andoh-Arthur, Knizek, Osafo, and Hjelmeland 2018). Masculinity does not entail a fixed entity embedded in bodies or behavioral traits; instead, it is conceptualized as a set of practices deployed in different societies to distinguish men from other men and from women (Cornwall and Lindisfarne 1994). Masculinity differs across economic, cultural, and temporal settings and is tied to prevailing gender relations in the society (Connell and Messerschmidt 2005). Excessive pressure to conform to traditional modes of masculinity increases the risk of men's suicidal behavior (Pirkis, Spittal, Keogh, Mousaferiadis, and Currier 2017; Struszczyk, Galdas, and Tiffin 2017). Across the sociopsychological literature, there is a plethora of evidence that associates male suicidal behaviors with triggers such as joblessness, unemployment, failure at work, relationship strains, depression, hopelessness, and substance use disorders (e.g., Coleman, Kaplan, and Casey 2011; Rivers 2014; Yang, Lau, Wang, Lau 2019).

Men's susceptibility to suicide is associated with socialization into gender roles. Men who hold more traditional masculine norms are more likely to be involved in health-impeding behaviors and are less likely to be engaged in health-promoting behaviors (Garfield, Isacco, and Rogers 2008). Men tend to hide vulnerability, ignore self-care, and reluctantly seek medical or professional help (Mahalik, Burns, and Syzdek 2007). These practices are likely to have adverse effects on various aspects of men's physical and mental health, swelling risks of disease, injury, and death (Courtenay 2000a; Garfield et al. 2008). The socially learnt norms of traditional masculinity restrict men's ability to seek support or disclose feelings, thus increasing the risk of suicide (Smalley, Scourfield, and Greenland 2005; Cleary 2012).

Conversely, women's socialization into gender roles encourages more healthpromoting behaviors and lifestyles. This possibly gives women more prevention and 
protection during health-related adversities (Courtenay 2000b). During crises, women demonstrate stronger protective capacities because of their social networks, family connectedness, and the value placed on the meaningfulness of life, while men are more likely to externalize their social and individual turmoil (Rutz and Rihmer 2007). During and after the Covid-19 pandemic, we urgently need suicide prevention strategies aimed at heightened male vulnerability (Cleary 2017) based on critical analyses of masculinity.

\section{Critical Masculinity and Suicide Prevention Interventions}

Early reports about male suicide during the Covid-19 pandemic agree about several triggering factors such as financial insecurities, fear of infections, social stigma, anxiety, and excessive regulations (Thakur and Jain 2020; Khan et al. forthcoming 2020). Due to patriarchal traditional masculine norms that discourage some men from showing weakness, cisgender males often feel restrained to disclose their emotional and physical pains to others, further predisposing them to ill-health and suicide. Men adhering to patriarchal normative roles may be reluctant to seek support due to fear of social stigma, mistreatment, or being viewed as weak or psychologically ill (Rivers 2014; Cleary 2019). Therefore, there is a pressing need for campaigns and programs that target men in order to minimize their resistance or unwillingness for accessing dedicated mental health and social wellbeing services.

The Covid-19 pandemic might open up opportunities for the enhancement of suicide prevention and intervention (Reger et al. 2020; Klomek 2020; Courtet et al. 2020). During the crisis, people may feel more comfortable to share their emotional burdens, anxiety, or suicidal ideation and are less likely to feel stigmatized (Klomek 2020; Molano 2020). Coupled with dedicated campaigns and programs, this might allow more men at risk of suicide to speak out and seek help. Before the pandemic, it was shown that increased availability of telephonic and social media helplines plays a positive role in men's health-seeking behavior (Schlichthorst, King, Reifels, Phelps, and Pirkis 2019). During the pandemic-propounded lockdown, such interventions may extend necessary social support and develop social networks for individuals with substantial risk factors for suicide (Courtet et al. 2020; Reger et al. 2020).

Pandemic-related unemployment could be a critical concern as wage employment is strongly associated with men's socially perceived role as primary providers and possible self-perception of failure in their role (Stack 2000; Scourfield, Fincham, Langer, and Shiner 2012; Rivers 2014; Rasmussen, Haavind, and Dieserud 2018; Andoh-Arthur et al. 2018; Mamun and Ullah 2020). In the light of heightened worldwide unemployment rates caused by the Covid-19 pandemic, Kawohl and Nordt (2020) estimate a global increase of between 2135 and 9570 additional suicide deaths per year. To minimize risk of suicide during the Covid-19 pandemic, governments should provide financial safety nets including food, housing, loans, and unemployment support along with more focused measures such as active labor market programs (Gunnell et al. 2020).

Growing suicide rates during the Covid-19 pandemic are linked to a combination of individual psychological and social responses to the crisis (Thakur and Jain 2020). Countering this disturbing trend requires both short-term and long-term responses and 
measures (Jandrić 2020) based on critical analyses of masculinity. In the long run, Covid-19-related male suicide requires a psychosocial policy framework suitable for times of crises and based on thorough research of factors of risk and protection (Gunnell et al. 2020). Therefore, suicide prevention interventions should be integrated into broader post-Covid-19 social reconstruction programs (Klomek 2020). In the short run, prevention of Covid-19-related male suicide requires a combination of urgent investment in campaigns and programs aimed at support-seeking, telephonic and social media helplines (Courtet et al. 2020; Reger et al. 2020), and targeted economic measures (Gunnell et al. 2020).

Based on preliminary research and incomplete data about male suicide available at the peak of the Covid-19 pandemic, this study needs to be understood as work in progress. However, pandemic-related suicide is an urgent problem which cannot be placed on hold. While we wait for more elaborate, substantial, and long-term research agendas and policy frameworks, studies such as this can serve as important inputs to immediate policy responses and strategies.

\section{References}

Andoh-Arthur, J., Knizek, B. L., Osafo, J., \& Hjelmeland, H. (2018). Suicide among men in Ghana: The burden of masculinity. Death Studies, 42(10), 658-666. https://doi.org/10.1080/07481187.2018.1426655.

Bhuiyan, A. K. M. I., Sakib, N., Pakpour, A. H., Griffiths, M. D., \& Mamun, M. A. (2020). COVID-19related suicides in Bangladesh due to lockdown and economic factors: Case study evidence from media reports. International Journal of Mental Health and Addiction. https://doi.org/10.1007/s11469-02000307-y.

Chang, S., Stuckler, D., Yip, P., \& Gunnell, D. (2013). Impact of 2008 global economic crisis on suicide: Time trend study in 54 countries. British Medical Journal, 347, f5239. https://doi.org/10.1136/bmj.f5239.

Cleary, A. (2012). Suicidal action, emotional expression, and the performance of masculinities. Social Science and Medicine, 74, 498-505. https://doi.org/10.1016/j.socscimed.2011.08.002.

Cleary, A. (2017). Help-seeking patterns and attitudes to treatment amongst men who attempted suicide. Journal of Mental Health, 26(3), 220-224. https://doi.org/10.3109/09638237.2016.1149800.

Cleary, A. (2019). The gendered landscape of suicide: Masculinities, emotions and culture. Cham: Palgrave Macmillan.

Coleman, D., Kaplan, M. S., \& Casey, J. T. (2011). The social nature of male suicide: A new analytic model. International Journal of Men's Health, 10(3), 240-252. https://doi.org/10.3149/jmh.1003.240.

Connell, R. W., \& Messerschmidt, J. W. (2005). Hegemonic masculinities: Rethinking the concept. Gender and Society, 19(6), 829-859. https://doi.org/10.1177/2F0891243205278639.

Cornwall, A., \& Lindisfarne, N. (1994). Dislocating masculinity: Gender, power and anthropology. In A. Cornwall \& N. Lindisfarne (Eds.), Dislocating masculinity: Comparative ethnographies (pp. 11-47). London: Routledge.

Courtenay, W. H. (2000a). Behavioral factors associated with disease, injury, and death among men: Evidence and implications for prevention. The Journal of Men's Studies, 9, 81-142 10.3149\%2Fjms.0901.81.

Courtenay, W. H. (2000b). Constructions of masculinity and their influence on men's well-being: A theory of gender and health. Social Science and Medicine, 50(10), 1385-1401 https://psycnet.apa.org/doi/10.1016 /S0277-9536(99)00390-1.

Courtet, P., Olié, E., Debien, C., \& Vaiva, G. (2020). Keep socially (but not physically) connected and carry on: Preventing suicide in the age of COVID-19. Journal of Clinical Psychiatry, 81, 20com13370. https://doi.org/10.4088/JCP.20com13370.

Durkheim, E. (1951). Suicide: a study in sociology. New York: The Free Press.

Garfield, C. F., Isacco, A., \& Rogers, T. E. (2008). A review of men's health and masculinity. American Journal of Lifestyle Medicine, 2(6), 474 487. https://doi.org/10.1177/1559827608323213.

Gunnell, D., Appleby, L., Arensman, E., Hawton, K., John, A., Kapur, N., et al. (2020). Suicide risk and prevention during the COVID-19 pandemic. The Lancet Psychiatry., 7, 468-471. https://doi.org/10.1016 /S2215-0366(20)30171-1. 
Iemmi, V., Bantjes, J., Coast, E., Channer, K., Leone, T., McDaid, D., Palfreyman, A., Stephens, B., \& Lund, C. (2016). Suicide and poverty in low-income and middle-income countries: A systematic review. The Lancet Psychiatry, 3(8), 774-783. https://doi.org/10.1016/S2215-0366(16)30066-9.

Jandrić, P. (2020). Postdigital research in the time of Covid-19. Postdigital Science and Education, 2(2), 233238. https://doi.org/10.1007/s42438-020-00113-8.

Kawohl, W., \& Nordt, C. (2020). COVID-19, unemployment, and suicide. Lancet Psychiatry, 7(5), 389-390. https://oi.org/10.1016/S2215-0366(20)30141-3.

Khan, A.R., Arendse, N., \& Ratele, K. (2020). Suicidal behavior and coronavirus (COVID-19): Insights from Durkheim's sociology of suicide. Mortality. In press.

Klomek, A. (2020). Suicide prevention during the COVID-19 outbreak. The Lancet Psychiatry, 7(5), 390. https://doi.org/10.1016/s2215-0366(20)30142-5.

Mahalik, J. R., Burns, S. M., \& Syzdek, M. (2007). Masculinity and perceived normative health behaviors as predictors of men's health behaviors. Social Science and Medicine, 64(11), 2201-2209. https://doi. org/10.1016/j.socscimed.2007.02.035.

Mamun, M., \& Ullah, I. (2020). COVID-19 suicides in Pakistan, dying off not COVID-19 fear but poverty? The forthcoming economic challenges for a developing country. Brain, Behavior and Immunity. https://doi.org/10.1016/j.bbi.2020.05.028.

Molano, S. (2020). Men, masculinity, violence and care in times of COVID-19. https://www.defyingenderoles. org/master-in-love/2020/4/16/men-masculinity-violence-and-care-in-times-of-covid-19. Accessed 29 May 2020.

Mooney, C., Kaplan, S., \& Denis, B. (2020). All across the United States, the coronavirus is killing more men than women, data show. The Washington Post, 5 April. https://www.washingtonpost.com/health/2020/04 /04/coronavirus-men/. Accessed 29 May 2020.

Naghavi, M. (2019). Global, regional, and national burden of suicide mortality 1990 to 2016: Systematic analysis for the global burden of disease study. British Medical Journal, 364, 194. https://doi.org/10.1136 /bmj.194.

Pirkis, J., Spittal, M. J., Keogh, L., Mousaferiadis, T., \& Currier, D. (2017). Masculinity and suicidal thinking. Social Psychiatry and Psychiatric Epidemiology, 52, 319-327. https://doi.org/10.1007/s00127-016-1324-2.

Rasmussen, M. L., Haavind, H., \& Dieserud, G. (2018). Young men, masculinities, and suicide. Archives of Suicide Research, 22(2), 327-343. https://doi.org/10.1080/13811118.2017.1340855.

Reger, M. A., Stanley, I. H., \& Joiner, T. E. (2020). Suicide mortality and coronavirus disease 2019-a perfect storm? JAMA Psychiatry. https://doi.org/10.1001/jamapsychiatry.2020.1060.

Rivers, J. (2014). Suicide and hegemonic masculinity in Australian men. In D. Lester, J. F. Gunn III, \& P. Quinnett (Eds.), Suicide in men (pp. 248-261). Springfield: Charles C. Thomas.

Rutz, W., \& Rihmer, Z. (2007). Suicidality in men-practical issues, challenges, solutions. The Journal of Men's Health and Gender, 4(4), 393-401. https://doi.org/10.1016/j.jmhg.2007.07.046.

Schlichthorst, M., King, K., Reifels, L., Phelps, A., \& Pirkis, J. (2019). Using social media networks to engage men in conversations on masculinity and suicide: Content analysis of Man Up Facebook campaign data. Social Media + Society, 5(4), 1-13. https://doi.org/10.1177/2056305119880019.

Scourfield, J., Fincham, B., Langer, S., \& Shiner, M. (2012). Sociological autopsy: An integrated approach to the study of men. Social Science and Medicine, 74, 466-473. https://doi.org/10.1016/j. socscimed.2010.01.054.

Smalley, N., Scourfield, J., \& Greenland, K. (2005). Young people, gender and suicide. Journal of Social Work, 5, 133-154 10.1177\%2F1468017305054953.

Stack, S. (2000). Suicide: A 15-year review of the sociological literature part I: Cultural and economic factors. Suicide and Life-threatening Behavior, 30(2), 145-162. https://doi.org/10.1111/j.1943-278X.2000. tb01073.x.

Struszczyk, S., Galdas, P. M., \& Tiffin, P. A. (2017). Men and suicide prevention: A scoping review. Journal of Mental Health, 28(1), 80-88. https://doi.org/10.1080/09638237.2017.1370638.

Suicide Awareness Voices of Education (2020). Preventing suicide during and after the Covid-19 pandemic. https://save.org/wp-content/uploads/2020/03/COVID-19-Tips-Final.pdf. Accessed 27 April 2020.

Thakur, V., \& Jain, A. (2020). COVID 2019-suicides: a global psychological pandemic. Brain, Behavior and Immunity. https://doi.org/10.1016/j.bbi.2020.04.062.

Tull, M. T., Edmonds, K. A., Scamaldo, K. M., Richmond, J. R., Rose, J. P., \& Gratz, K. L. (2020). Psychological outcomes associated with stay-at-home orders and the perceived impact of COVID-19 on daily life. Psychiatry Research, 289, 113098. https://doi.org/10.1016/j.psychres.2020.113098.

Vijayakumar, L. (2015). Suicide in women. Indian Journal of Psychiatry, 57(2), S233-S238. https://doi. org/10.4103/0019-5545.161484. 
World Health Organization (2019). Suicide. https:/www.who.int/news-room/fact-sheets/detail/suicide. Accessed 16 March 2020.

Yang, X., Lau, J. T. F., Wang, Z., \& Lau, M. C. M. (2019). Prevalence of binge drinking and relationships between masculine role discrepancy and binge drinking via discrepancy stress among Chinese men. Drug and Alcohol Dependence, 196, 57-61. https://doi.org/10.1016/j.drugalcdep.2018.12.013. 